\title{
The African Commission on Human and People's Rights and the woman question
}

\author{
Ebenezer Durojaye and Olubayo Oluduro
}

\begin{abstract}
This paper proposes that in developing jurisprudence on women's rights, the African Commission will need to ask the woman question, particularly the African woman question. The woman question requires a judicial or quasi-judicial body to always put woman at the centre of any decision with a view to addressing the historically disadvantaged position of women in society. Asking the African woman question means examining how the peculiar experiences of African women have been ignored by laws rooted in patriarchy across the region. Although the Commission has handled few cases directly dealing with women's rights, the paper suggests that the Commission can draw inspiration from decisions of other regional and international human rights bodies such as the European Court on Human Rights and the Committee on Elimination of All Forms of Discrimination against Women (CEDAW Committee) on how to ask the woman question. The paper recommends that in line with feminist reasoning, there is a need for the African Commission to develop a consistent gender-sensitive approach in dealing with cases that may have implications for women. In essence, the African Commission must ask the African woman question when dealing with cases on the enjoyment of women's fundamental rights.
\end{abstract}

\section{Introduction}

In 2016, the human rights community in Africa will celebrate the 35th anniversary of the adoption of the African Charter on Human and Peoples' Rights (African Charter), the 3oth anniversary of the establishment of the African Commission on Human and Peoples' Rights, the body responsible for implementing the provisions of the Charter, and 11th anniversary of the entry into force of the Protocol to the African Charter on the Rights of Women (African Women's Protocol). Indeed, the African Union has deemed it fit to declare 2016 as the Human Rights year with a focus on women. This could not have come at a better time. To date, the Commission is yet to develop its jurisprudence with regard to women's rights. This is hardly the fault of the Commission as very few communications that directly touch on women's rights have been submitted to it. The purpose of this article is to assess the approach of the Commission to the few Communications so far decided, and suggest how the Commission can develop a gendersensitive approach to communications that may be filed before it in future. In this regard, the Commission can ask the woman question with regard to Communications that may relate to the violation of women's rights. On a daily basis, women across Africa continue 
to face discriminatory practices and are treated unfairly in every facet of human endeavour. Despite the fact that the Constitutions of most African countries recognise that every citizen shall enjoy equality of rights, obligations and opportunities before the law, women have remained subject to patriarchal tradition. It is obvious that meeting most of the Sustainable Development Goals (SDGs) will remain difficult, if not impossible if harmful socio-cultural practices (such as widowhood rites, female genital mutilation, widow cleansing and child marriages, among others) are not addressed. The law must help women to demand and get their legitimate rights: for education, equal opportunities, independence, bodily (sexual) safety and freedom from violence and other human rights abuses.

Over the years, attempts have been made at international and regional levels for the promotion and protection of the human rights of women. In 1979, the United Nations General Assembly adopted the first human rights treaty on women-the Convention on the Elimination of All Forms of Discrimination against Women (CEDAW). This treaty came into force in 1981 and is today regarded as the International Bill of Women's Rights. This treaty has been widely ratified by countries of the world, including African countries. Other developments at the international level with regard to the advancement of women's rights include declarations and consensus statements such as the 1993 UN Declaration of Violence against Women, the Vienna Declaration and Programme of Action, the International Conference on Population and Development (UN 1994) and the Fourth World Conference on Women (UN 1995). During the Vienna Conference on human rights, it was noted that sexual harassment and exploitation of women, including those arising from cultural prejudice are incompatible with the dignity and worth of human person and must be eliminated (UN 1993, para. 18). This sentiment was echoed at both the International Conference on Population and Development (ICPD) and the Fourth World Conference on Women (FWCW). At these conferences, the international community noted that low socio-economic status of women, acts of discrimination and their exposure to violence will impact negatively on their health and well-being (ICPD, para 4.1; FWCW, para. 92). Therefore, governments were enjoined to take drastic measures with a view to addressing discriminatory practices against women and girls (ICPD, para 4.1; FWCW, para. 92).

At the regional level, the African Union in 2003 adopted the Protocol to the African Charter on the Rights of Women (African Women's Protocol). This document contains a number of radical and progressive provisions relating to the promotion and protection of women's rights in Africa. The adoption of the African Women's Protocol is an attempt to address the inadequacies of the African Charter with regard to the advancement of women's rights. All these developments have brought to the fore the need to recognize women's rights as human rights and to ensure respect for their sexual and reproductive health and rights. However, despite these developments, discriminatory practices against African women have persisted. Indeed, African women have continued to play subordinate roles in society and are denied equal rights to economic opportunities. This is a clear indication that the existence of treaties and laws protecting women's rights will not suffice unless regional human rights bodies and courts play more active roles in advancing women's rights as guaranteed in regional human rights instruments or national constitutions. 
Against this backdrop, this paper examines how cultural and religious practices have continued to serve as sources of human rights violations for African women. The paper proposes that in developing jurisprudence on women's rights, the African Commission will need to ask the woman question, particularly the African woman question. The woman question requires a judicial or quasi-judicial body to always put woman at the centre of any decision with a view to addressing the historically disadvantaged position of women in society. Asking the African woman question means examining how the peculiar experiences of African women have been ignored by laws rooted in patriarchy across the region. While it is noted that the Commission has handled few cases directly dealing with women's rights, the paper suggests that the Commission can draw inspiration from decisions of national courts and other regional and international human rights bodies such as the Committee on Elimination of All Forms of Discrimination against Women (CEDAW Committee) on how to ask the woman question. The paper recommends that in line with feminist reasoning, there is a need for the African Commission to develop a consistent gender-sensitive approach in dealing with cases that may have implications for women. In essence, the African Commission must ask the African woman question when dealing with cases that may have implications for the enjoyment of women's fundamental rights.

\section{What is asking the African woman question?}

According to Joyner (1997, p. 183), asking the woman question means "examining how the law fails to reflect the experiences and values that seem more typical of women than of men". The method similarly recognises the fact that historically, women have been, and are, in fact still, a disadvantaged group that requires special attention. Specifically with regard to law, asking the woman question would imply examining how the law has omitted to reflect experiences and values that are more peculiar to women than men. Or in another sense, it may enquire into how existing law can be disadvantageous to women (Cook 1995a, p. 986). Asking the woman question operates on the assumption that certain laws are not only neutral, but may also be biased towards women by entrenching patriarchal traditions. Thus, the woman question aims at exposing the lacuna in the law with regard to women's needs, and how this might be corrected.

When one considers how cultural and religious practices together with violence against women have continued to erode women's human rights in Africa, it becomes necessary that national courts and regional human rights bodies such as the African Commission should do more than ask the woman question; they must ask the African woman question. The African woman question should respond to the peculiar circumstances of African women who are confronted on a daily basis with cultural and religious practices that relegate them to the background. All in the name of culture and tradition, the African woman is assigned the role of homemaker and child-bearer. She merely earns respect as a wife in society by proving her fecundity. Tamale (2004, p. 52) could not have put it better when she observes as follows:

In Africa, it does not matter whether a woman is a successful politician, possesses three Ph.Ds and runs the most successful business in town; if she has never married and/or is childless, she is perceived to be lacking in a fundamental way. Girl children 
are raised and socialized into this ideology and few ever question or challenge its basic tenets. Single, childless women carry a permanent stigma like a millstone about their necks. They are viewed by society as half-baked, even half-human. Thus, the domestic roles of mother, wife and homemaker become the key constructions of women's identity in Africa.

It is not for the African woman to decide the spacing or numbers of her children, that privilege belongs to her husband. This has put undue pressure on her and caused her to endure unwanted pregnancies and contributed to the high maternal mortality in the region.

Maternal deaths are preventable and have almost been eliminated in developed countries (WHO et al. 2014). There is no reason why a woman should die in Africa in a bid to bring forth another life. Experience has shown that high maternal mortality in Africa is aggravated due to socio-cultural practices that undermine the human rights of women and accord little regard for the lives of African women. For instance, early/child marriage remains a serious threat to the health and well-being of the girl child. An estimated 125 million girls are married before they reach the age of 18 in Africa (UNICEF 2015). Early/child marriage can aggravate maternal death as girls under 18 who become pregnant are five times more likely to experience complications during birth compared to their counter-parts who are 20 and above (UNFPA 2012). Africa does not lack the expertise nor the resources to prevent women from dying during pregnancy or childbirth, but the challenge is that African governments have not demonstrated enough political will to address this health challenge. This situation warrants asking the African woman question. Why should African women continue to die needlessly during childbirth or pregnancy when their counterparts in developed region have nearly eliminated this challenge? Why is it that African governments have failed to make it their priority to reduce maternal deaths in the region?

Other cultural practices such as Female Genital Cutting/Mutilation (FGC/M) continue to endanger the health and well-being of African women and girls. The WHO (2016) estimates that 100-140 million girls and women worldwide are currently living with the consequences of the FGC/M. It is mostly carried out on young girls at some point between infancy and the age of 15 years. In Africa, an estimated 92 million girls from 10 years of age and above have undergone FGC/M (WHO 2016). More than 200 million girls and women alive today have been cut in 30 countries in Africa, the Middle East and Asia where FGC/M is concentrated (WHO 2016). Another estimated 3 million girls are at risk of FGC/M annually. The practice and social acceptance of FGC/M persists in many countries (UNICEF 2013). FGC/M constitutes human rights violations as it threatens the rights of the girl child to life, dignity, non-discrimination, health and freedom from inhuman and degrading treatment.

In many parts of Africa, women continue to experience difficulty with regard to access to economic opportunities, particularly land holding. The situation is compounded by the fact that most cultures and traditions often deny female children rights of inheritance. Antediluvian customs still regard female children inferior to their male counterparts, and as such do not accord female children equal rights and opportunities with male 
children. In some situations, women in Africa are made to undergo traumatic widowhood practices in order to show that they have nothing to do with the death of their husbands (Durojaye 2013, pp. 176-196). Some other women are forced to marry relatives of their deceased husbands or have sexual intercourse with a stranger to cleanse them of evil forces that might have caused the death of their husbands. Despite the fact that many African countries have constitutions that guarantee the right to nondiscrimination and have ratified international and regional human rights instruments that protect all individuals, including women, from discrimination, African women remain subject to discriminatory practices. This calls for asking the African woman question.

Across the region, violence against women, including domestic violence remains the norm. Every minute a woman in one corner of Africa suffers from violence. In most cases, gender-based violence, particularly sexual violence is rooted in patriarchal tradition and unequal power relations. Indeed, some studies have shown that while boys are permitted to experiment with multiple sexual partners to exhibit strength and virility, girls are expected to be sexually passive and 'well- behaved' (Durojaye 2013, pp. 176196). This would seem to the point made by Gilligan (1982) in her seminal work In a Different Voice: Psychological Theory and Women Development. In that book, Gilligan (1982, pp. 25-51) observes that male and female children tend to exhibit different characteristics while growing up. Essentially, Gilligan's study attempted to ascertain whether there is a distinctively feminine way of thinking or solving problems different from that of men. According to her, girls tend to evoke the 'ethic of care' and tend to see things in terms of relationship, responsibility, caring, context and communication (Gilligan 1982, pp. 25-51). However, boys usually rely on the 'ethic of rights' or 'justice' and tend to analyse problems in abstract terms of right and wrong, fairness, logic, rationality, winners and losers, thus, ignoring context and relationships.

Indeed, traditional social psychology believes that 'normal' and natural behaviour for men include aggression, tenacity, curiosity, ambition, responsibility and competition. By contrast, 'normal' behaviour for women includes passivity, affection, emotion, obedience, and responsive approval (Eisenstein 1984, pp. 11-26). The conclusion that can be drawn from Gilligan's work is that society often ascribes different roles to men and women, which may perpetuate the low status of women and girls. This tends to further render women vulnerable to abuse and other human rights violations, including acts of violence.

Although Gilligan's study was conducted almost 30 years ago, the situation today is not so different. Buttressing Gilligan's study, Odejide (2007) has noted that female students are usually portrayed and treated as subordinate to their male counterparts. She notes further that this is due to traditional cultures and social familial factors, which often perceive women as fragile, dependent on male protection and in need of surveillance and control of their behaviour. It is further revealed in Odejide's study that female students' sexual agency is limited as compared with their male counterparts by some cultural and traditional beliefs. Violence against women is not only a threat to women's physical and psychological well-being, but can also expose women to sexually transmitted infections including HIV/AIDS. 
Women are mothers, wives, sisters, daughters, nurses, doctors, lawyers and journalists. Many give birth, feed their babies, train and inculcate values in them. A woman's life affects her immediate family, neighbourhood, village and nation. On a broad scale, a nation's economy and social advancement (particularly in Africa) depends to a reasonable extent, on the contributions of women (Forum for African Women Educationists 1995). When a woman's status is improved through sound education, adequate health care, freedom from psychological and physical abuse and violence, then the society stands a better chance of overall economic and social progress.

Indeed, in so many ways, feminists in Africa have asked the African woman question. When Eboh (1997, pp. 333-337) argues that it is demeaning of African women to be consigned merely to the role of child-bearers and home keepers, she is asking the African woman question. Also, when Maria Ba (1981) in her award- winning novel So Long a Letter exposes the ills of some cultural and religious practices such as polygamy and wife inheritance that African women are required to endure with humility, she is asking the African woman question. At other times, Tamale (2004, p. 50) has asked the African woman question when she questions the patriarchal arrangements of African societies that limit economic opportunities for women, defines women's lives by the ideology of domesticity and fail to acknowledge women's contribution to labour productivity in the region. More importantly, Banda (2005) has asked the African woman question when she concludes that laws and institutional frameworks on women in Africa are structured in a way that disadvantages women.

It should be noted that African women are not by any means homogenous. They differ in terms of their age, socio-economic status, sexual orientation, disability, rural/urban dichotomy, and so forth. This intersectionality is important to bear in mind when asking the African woman question. Despite this diversity, it has been argued that a common denominator to all African women is the gender-based discrimination they encounter on a daily basis in their different lives (Banda 2005; Tamale 2004). Though very important, due to lack of space, this paper does not consider in detail the nexus between intersectionality and the African woman question. It merely sets out to assess whether the jurisprudence of the African Commission has reflected the lived experiences of African women.

It has further been contended that the socio-cultural and legal institutions in Africa are structured in such a way that they potentially limit women's human rights (Banda 2005). In essence, it is believed that the patriarchal nature of the African societies limits women's capability to explore opportunities and live to their fullest potential.

On the other hand, some African feminist scholars (Oyewumi 1997; Nzegwu 2006) have rejected the argument that African culture tends to disadvantage women and reduce them to second class citizens. It is contended that this conclusion was reached based on ignorance or lack of understanding of the African way of life. For instance, Oyewumi (1997) has noted that women have always played an important role in African societies and debunked the assertion that they have always played 'second fiddle' to men. Using the Yoruba culture as a case study, she argues that age rather than anatomy determines 
position and status in society. In essence, sex difference has no normative implications beyond anatomical distinction. In her view, the African culture is designed in such a way that men and women are assigned to play crucial roles in ensuring peace and harmony in society. Nzegwu (2006) similarly noted that while traditional African institutions were hierarchical, they were never patriarchal as both men and women had important roles to play in administering society. She submits that owing to ignorance, Western feminist gender analysis typically treats any kind of social hierarchy or sex difference as oppressive.

Also, Tamale (2008) has noted that Western scholars tend to make erroneous conclusion that all African cultures are bad and capable of eroding the human rights of women. In her view, this is misleading as some African cultures are positive and do promote harmony and congruity in society. While she admits that some cultural practices in Africa can be harmful, she contends that this is not peculiar to Africa and therefore it is misleading to label all African cultures as harmful and as potential threats to human rights. Tamale (2008, p. 51) submits that such arguments are not only dangerous but also myopic and tend to "create an extremely restrictive means by which African women challenge domination”.

Asking the African woman question is very important in that it enables judicial or quasijudicial bodies such as the African Commission to contextualize the lived experience of African women before arriving at any decision. Such a question helps in framing the appropriate remedy that will meet the needs of African women. It will also assist in addressing some of the historical disadvantage of African women and how this can be properly addressed. The African woman question will allow courts or other bodies to enquire into how laws, policies and programmes are potentially discriminatory of African women.

Recent decisions in some African countries show that courts are beginning to take a proactive stance in striking down laws and practices that continue to discriminate against women. Examples of such decisions include the Bhe case ${ }^{1}$ where the Constitutional Court rejected and declared as unconstitutional the primogeniture customary practice, which tends to favour male children over female in inheritance matters. According to the court, this practice is discriminatory and violates the equality clause in the South African Constitution. More recently, the Court of Appeal in Botswana has struck down a similar customary practice that denies rights of inheritance to a female child. ${ }^{2}$ The court held that given Botswana's commitment to human rights standards evidenced by ratification of international and regional human rights instruments, this discriminatory cultural practice could not be justified. The court declared that the customary practice is inconsistent with the spirit and letters of the Constitution of Botswana. Also, the Nigerian Supreme Court has struck down an agelong cultural practice in the Eastern part of the country, which denies inheritance rights

\footnotetext{
${ }^{1}$ Bhe \& Others v. Magistrate Khayelitsha [2005 (1) BCLR 1 (Constitutional Court)].

${ }^{2}$ Ramantele v. Mmusi and Others (CACGB-104-12) [2013] BWCA 1 (Botswana Court of Appeal).
} 
to female children. 3 The Court declared that such a cultural practice is inconsistent with the non-discriminatory provision of the Nigerian Constitution (section 42(1) and (2) of the Constitution of the Federal Republic of Nigeria, 1999 (as amended)) and its obligation under international law. These decisions are positive developments that demonstrate the willingness of national courts in Africa to ask the woman question.

\section{What is asking the woman question?}

In order to understand clearly how the African question should be asked, one can draw experience from other parts of the world where the woman question has been asked. Feminist scholars from the north have often asked the woman question to challenge the injustices meted out to women. In her seminal article titled 'Feminist Legal Methods,' Bartlett (1990, p. 829) has identified three different feminist methods that can be adopted to respond to human rights violations experienced by women. These include feminist practical reasoning (Bartlett 1990, p. 829), 4 feminist consciousness raising (Mackinnon 1982, p. 29) 5 and asking the woman question. This paper only focuses on the last method-asking the woman question. According to Bartlett, feminists often ask a set of questions known as 'the woman question', designed to Identify the gender implications of rules and practices which might otherwise appear to be neutral or objective (Bartlett 1990, p. 837). The woman question queries the various forms of inequalities women have been subjected to, demanding whether there is justification for women's different roles and subjugation in society. Bartlett further explains that relating to enacted law, asking the woman question means questioning how the existing legal rules and standards may disadvantage women (Bartlett 1990, p. 851). The essence of the woman question is to expose certain features of the law that are discriminatory and how these can be corrected.

With respect to judicial decisions, the woman question will ask if a judge handling a divorce suit or a rape case, for example, has taken into consideration, before arriving at his or her judgment, the peculiar 'life experiences' of women. Far from applying the law in a neutral sense, the woman question will require a judge to reflect on the disadvantaged position of women and how this may have implications for them in such cases. Asking the woman question in the situations mentioned above, involves challenging the status quo which has placed men above women in many societies, including the African societies.

In what may be regarded as justifying the need to ask the woman question, Wishek (1985, pp. 64, 68) opines as follows:

\footnotetext{
${ }^{3}$ Ukeje v. 2014] All FWLR (pt. 730) 1323 at 1341.

${ }^{4}$ Practical reasoning as a method tackles problems not as "dichotomized conflicts but as dilemmas with multiple perspectives, contradictions and inconsistencies" (Bartlett 1990, p. 829). Feminist practical reasoning admits differences in human experiences and the importance of taking into consideration competing or inconsistent claims. However, it does not hide its bias by indicating which moral and political choices underlie that bias.

${ }^{5}$ In Mackinnon's words (1982, p. 29), feminist consciousness-raising refers to "the collective critical reconstruction of the meaning of women's social experience, as women live through it". Feminist consciousness-raising aims at creating knowledge through exploring experiences that derive from sharing of life events The kernel of consciousness-raising is to draw the attention of governmental and non-governmental institutions and the public at large, via the media, political campaigning, lobbying and even the arts, to the challenges women encounter by reason of patriarchy
} 
If in the course of our criticism of law and collection of information about women's experiences of law, we fail to ask all the questions about how to know, as well as about what is known, we risk legitimizing patriarchy again, even as we attempt to change it. ${ }^{6}$

The woman question requires the judge to 'wear a gender lens' which will enable him or her to see beyond laws or rules that seem innocuous on the surface but are indirectly full of discriminatory contents. In such a situation, the judge is by no means called upon to do a favour to women; rather he or she is called upon to apply the law in such a way that will pay attention to the lived experiences of women. Explaining this further, Bartlett (1990, p. 846) reasons as follows:

Asking the woman question does not require decision in favour of a woman. Rather, the method requires the decision maker to search for gender bias and to reach a decision in the case that is defensible in light of that bias. It demands, in other words, special attention to a set of interests and concerns that otherwise may be, and historically have been, overlooked. The substance of asking the woman question lies in what it seeks to uncover: disadvantage based upon gender.

The woman question can be asked in a number of situations. When feminists seek equality in access to employment and to equal pay, equality in voting rights and prohibition of sexual violence, they can be said to be asking the woman question. As far back as the early 2oth century, Margaret Sanger (cited in St. John-Stevas 1956, pp. 70-74) had asked the woman question when against all odds she advocated for the use of contraception to limit family size in order to preserve the health of a woman. Also, when Cook (1995b, p. 5) suggests the re-characterization of human rights law to be more responsive to women's needs, she is merely asking the woman question.

Furthermore, when Bunch (1995, p. 12) calls for the transformation of human rights to pay more attention to women's rights, she is asking the woman question. In modern times, feminists ask the woman question in various areas of human lives. For instance, they ask: why should women require corroboration before they are believed in rape cases; or why should girls undergo female genital cutting/mutilation (FGC/M) or be subjected to virginal testing? Or why should women and girls require the consent of their husbands or parents to seek medical attention? At other times, they have asked: why should a woman be punished by a religious law for engaging in a consensual sexual act with a man who may escape punishment by simply denying knowing the woman? Specifically, in relation to the status of girls, Lees and Mellor (1986, pp. 164, 165) have asked: why is it that so few girls develop to their full potential, why are they subject to

\footnotetext{
${ }^{6}$ Wishik has further asked seven important questions feminists often asked, which include: (1) What have been and what are now all women's experiences of the 'Life Situation' addressed by the doctrine, process, or area of law under examination? (2) What assumptions, descriptions, assertions and/or definitions of experience-male, female, or ostensibly gender neutral — does the law make in this area?... (3) What is the area of mismatch, distortion, or denial created by the differences between women's life experiences and the law's assumptions or imposed structures?... (4) What patriarchal interests are served by the mismatch?... (5) What reforms have been proposed in this area of law or women's life situation? How will these reform proposals, if adopted, affect women both practically and ideologically?... (6) In an ideal world, what would this woman's life situation look like, and what relationship, if any, would the law have to this future life situation?... and (7) How do we get there from here?
} 
discrimination in the home and outside; and why are they subject to sexual abuse and harassment?

By asking these questions, feminists are able to expose how institutions, political choice and institutional arrangements combine to perpetuate the subordination of women in society. In the absence of the woman question, the suffering of women usually due to their sex is often rendered invisible and almost ignored, thereby exacerbating women's position in society. The woman question helps reveal the fact that women's disadvantaged position in society is a product of patriarchy, rather than their inherent characteristics (Bartlett 1990, p. 843). Equally, it helps to expose the hidden effects of certain laws that are discriminatory against women based on their sex, thereby revealing how social structures harbour norms that subjugate women's rights as compared to men in society (Bartlett 1990, p. 846). The essence of asking the woman question does not necessarily require that a decision must be in favour of a woman. Instead, what it does is that it allows a decision maker to reflect on the gender implications of his or her decision so that in the end, the decision will not be biased towards women. ${ }^{7}$

\section{The jurisprudence of the African Commission and the woman question}

This section of the article discusses whether the African Commission has attempted to ask the African woman question in some of its jurisprudence. It should be noted that the African Commission through its mandate-promotional and protective- has the potential to ask the African woman question (Evans and Murray 2008; Viljoen 2012). However, the focus of this article is to assess the jurisprudence of the Commission with a gender lens to ascertain whether it has reflected the lived experiences of African women. As observed earlier, the African Commission has so far entertained few communications directly touching on women's rights. Nonetheless, there have been some occasions where cases before the Commission could have implications for the enjoyment of women's rights and fundamental freedoms. While it is noted that the African Commission has developed rich jurisprudence that may have implications for women's rights, the article focuses on two cases to illustrate whether the decisions of the Commission have been gender- sensitive.

It should be noted that article 2 of the African Charter provides that everyone is equal before the law and that no one should be discriminated against on grounds such as gender, religion, political beliefs or other status. Article 3 similarly guarantees to every individual the right to equality and equal protection of the law. Specifically relating to women, articles 1 and 2 of the African Women's Protocol (2003) prohibit discriminatory practices against women. Article 1 defines discrimination against women broadly to include:

Any distinction, exclusion or restriction or any differential treatment based on sex and whose objectives or effects compromise or destroy the recognition, enjoyment or the

\footnotetext{
7 For excellent examples of putting 'the woman question' and other forms of feminist legal reasoning into practice, see the various Feminist Judgments Projects: Hunter et al. (2010), Douglas et al. (2015), Stanchi et al. (2016), Enright et al. (forthcoming 2017).
} 
exercise by women, regardless of their marital status, of human rights and fundamental freedoms in all spheres of life. ${ }^{8}$

The African Commission in the case of Legal Resource Foundation $\mathrm{v}$ Zambia9 has explained the relevance of articles 2 and 3 of the African Charter dealing with nondiscrimination and equal protection of the law. According to the Commission:

The right to equality is very important. It means that citizens should be expected to be treated fairly and justly within the legal system and be assured of equal treatment before the law and equal enjoyments of all the rights available to all other citizens. The right to equality is important for a second reason. Equality or lack of it affects the capacity of one to enjoy many other rights. ${ }^{10}$

This decision provides a strong basis for arguing that cultural practices that perpetuate the low status of women are not only discriminatory, but also demeaning. Thus, it is obligatory upon African governments to ensure that women and girls are not subjected to the harmful cultural practices discussed in this paper. The discussion that follows examines how the African Commission has responded to the African woman question in two of its decisions that directly touch on women's rights and other cases indirectly affecting women's rights.

\section{The Doebbler case}

While the African Commission is yet to specifically explain the provisions of articles 2 and 3 in the context of women's rights, the Commission, in Curtis Francis Doebbler v. Sudan ${ }^{11}$ (Baderin 2005, p. 133) has given a broad interpretation to the legal obligations imposed by article 5 on states. In that case, eight Muslim University students on a picnic were arrested and charged with committing, in a public place, acts contrary to public morality, prohibited under article 152 of the Sudanese Criminal Law of $1991 .^{12}$ The provision of that law prohibits acts such as girls/women wearing trousers, kissing or dancing with boys/men, crossing legs with boys/men, sitting with boys/men and sitting and talking with boys/men. The female students were subsequently convicted and sentenced to fines and lashes, which would be carried out in public under the supervision of the national court. While the language of the law would seem, neutral and could apply to boys/men and girls/women, in practice, the provision has tended to be invoked against women and girls (Amnesty International 2010,p.4). The complainants alleged that the punishment violated article 5 of the African Charter. It was alleged that the female students were sentenced to fines and between 25 and 40 lashes and that the

\footnotetext{
${ }^{8}$ Protocol to the African Charter on Human and Peoples' Rights on the Rights of Women in Africa, 11 July 2003 (known as African Women's Protocol

${ }^{9}$ Legal Resource Foundation v. Zambia (2001) AHRLP 84 (ACHPR 2001) para 63.

${ }^{10}$ Ibid 63.

${ }^{11}$ Doebbler v. Sudan (2003) AHRLR 153 (ACHPR 2003).

${ }^{12}$ Article 152 of the Sudanese Criminal Law of 1991provides as follows: 1. Whoever commits, in a public place, an act, or conducts himself in an indecent or immoral dress, which causes annoyance to public feelings, shall be punished, with whipping, not exceeding forty lashes, or with fine, or with both. 2 . The act shall be deemed contrary to public morality, if it is so considered in the religion of the doer, or the custom.
} 
lashes were carried out in public on the bare backs of the women using a wire and plastic whip that leaves permanent scars. According to the complainants:

the punishment of lashings is disproportionate and humiliating because they require a girl to submit to baring her back in public and to the infliction of physical harm, which is contrary to the high degree of respect accorded to females in Sudanese society (Curtis Francis Doebbler v. Sudan, para. 8).

It was argued that this constitutes inhuman and degrading treatment. Finding in favour of the complainants and requesting the abolition of the penalty of lashes in Sudan, the Commission noted as follows:

Article 5 of the Charter prohibits not only cruel but also inhuman and degrading treatment. This includes not only actions which cause serious physical or psychological suffering, but which humiliate or force the individual [to act] against his will or conscience (Curtis Francis Doebbler v. Sudan, para. 36).

The Commission noted further that the prohibition of torture, cruel, inhuman or degrading treatment or punishment is to be interpreted as widely as possible to encompass the widest possible array of physical and mental abuses. ${ }^{13}$ From this broad explanation of the nature of the right to dignity by the Commission, it would appear that the provision of article 5 of the African Charter can be interpreted to apply to the adoption of cultural practices that are discriminatory against women and that deny them their fundamental rights and freedoms. It is a known fact that some of the cultural practices cause women untold hardship and trauma and in some cases, damage their emotional and physiological well-being. Therefore, this situation will come under the broad interpretation the Commission has given to the term 'inhuman and degrading treatment'. Indeed, it is not in contention that some of the negative cultural practices discussed above are potentially threatening to the lives and well-being of women and girls. The Commission did not consider the implications of Shari'a for the enjoyment of women's rights in Sudan. It notes that the Commission 'was not invited to interpret Islamic Shari'a Law as obtains in the Criminal Code of the Respondent State. No argument was presented before it nor did the African Commission consider arguments based on the Shari'a Law'.14 It concludes that the Commission was only required to examine the application of the African Charter in the legal system of Sudan.

It should be noted that when women and girls are made to undergo some of these negative cultural practices, their dignity as human beings is undermined. Margalit (2003, p. 220) has explained that dignity, unlike honour, is not a positional good, rather it should be accorded to everybody, by virtue of the most universal common denominator of being human. As the Commission rightly pointed out:

\footnotetext{
${ }^{13}$ Ibid para 37.

${ }^{14}$ Ibid para 41.
} 
There is no right for individuals, and particularly the government of a country to apply physical violence to individuals for offences. Such a right would be tantamount to sanctioning State sponsored torture under the Charter and contrary to the very nature of this human rights treaty. 15

The decision in Doebbler is highly commendable as the African Commission was able to demonstrate its sensitivity to the plight of women and girls. The Commission was able to contextualize the suffering and indignity of women and girls as a result of oppressive religious laws and practices. In some parts of Africa, religious laws have often been invoked to deny women and girls their fundamental rights. For example, the introduction and application of Shari'a law in the northern parts of Nigeria shortly after the country's return to democratic rule in 1999, has sparked heated debate. Some provisions of Shari'a in Nigeria hinder access to sexual and reproductive health care services to women and girls by requiring them to obtain the consent of their husbands or parents before seeking medical attention. Also, Shari'a in Nigeria forbids premarital sexual intercourse and punishes consensual sexual acts between two adults outside of wedlock. Of particular importance is the celebrated case of Commissioner of Police, Katsina State v. Amina Lawal and Yahaya Mohammed ${ }^{16}$ where the accused was sentenced to death by stoning for engaging in sexual acts outside of wedlock. The conviction was later quashed by a Shari'a Court of Appeal. Imam (2000, pp. 16-31) has argued that the implementation of Islamic law in Nigeria is often based on misconception and lack of understanding. Conversely, this tends to undermine the rights and dignity of women.

In general, one may argue that the provisions of Shari'a place an onerous burden on women and girls as compared to their male counterparts. This is because often women are at the receiving end of the punishments prescribed under the law. As seen from the Doebbler case while the language of the law would seem to be general, its implementation has been targeted at women and girls. Therefore, the fact that the Commission not only found a violation of article 5 of the African Charter, but also requested that the government of Sudan should repeal the offensive provision of the Criminal Law, is a proactive step to advancing the human rights of women and girls. Moreover, given that the aim of the Sudanese Criminal law is to control and repress the sexuality of women and girls, the African Commission by its positive decision calling for the repeal of the law, is in effect asking the woman question. Why is the provision of article 152 of Sudanese Criminal Law targeted at girls and not at boys? As the Commission correctly pointed out, such a discriminatory approach of the law impugns the dignity of women and girls. By this decision, the Commission would seem to have taken into cognizance the lived experiences of women and girls in Africa who are suffocating under oppressive religious and cultural laws.

One noticeable shortcoming of this decision is the failure of the Commission, in line with article 61 of the African Charter, to draw inspiration from international human rights

\footnotetext{
${ }^{15}$ Ibid para 42.

${ }^{16}$ Unreported case no 9/2002 delivered on 20 March 2002.
} 
principles and standards to elucidate its point. Given that the CEDAW Committee has issued important General Recommendations on women's rights, particularly General Recommendation 19 on violence against women, one would have expected the Commission to apply the useful document and other relevant human rights norms as interpretative guides. In addition, the Commission could have drawn inspiration from the decisions of other human rights bodies such as the European Court of Human Rights. For instance, the European Court in Aydin v. Turkey has demonstrated more willingness to ask the woman question with regard to sexual violence perpetrated against a woman detainee. ${ }^{17}$

Moreover, while the Commission would seem to be comfortable declaring the Sudanese Criminal Code in question unconstitutional, it was, however, reluctant in providing compensation to the women and girls who have suffered human rights violations by the implementation of this law. That would seem to be a missed opportunity to ask the African woman question and provide a soothing balm to the injury experienced by the female students. Since the Commission agreed that the female students in question have suffered from indignity as a result of the Criminal Code, the appropriate approach, in line with international practice reflected in the works of the CEDAW Committee, would have been to award damages to the victims of this human rights violation. This would not only send a strong warning to other governments that apply laws that erode women's fundamental rights and freedom, but will also confirm that the Commission is truly sensitive to the lived experiences of women and girls.

\section{The Egyptian Initiative for Personal Rights Case}

Another important case that raises the woman question before the African Commission is the case of Egyptian Initiative for Personal Rights \& INTERIGHTS v. Egypt. ${ }^{18}$ While this case raises various acts of human rights violation, the focus will be on the implications of sexual violence for the enjoyment of women's rights to dignity and nondiscrimination. In this case, four female journalists alleged various acts of human rights abuses against the government of Egypt in 2005. According to the communication, the four victims were among some people who experienced violence and physical abuse from the hands of government security agents during the 2005 referendum to amend article 75 of the Egyptian Constitution. During the referendum, violence broke out and some demonstrators and journalists were molested by anti-riot policemen and the supporters of National Democratic Party (NDP). It is alleged that in a bid to quell the violence, demonstrators and journalists, including the four female victims were subjected to acts of intimidation, insults and sexual harassment. Each of the four women narrated their sordid tales of how they were physically abused and assaulted by the anti-riot policemen and supporters of NDP.

\footnotetext{
${ }^{17}$ Aydin v. Turkey (European Court of Human Rights) Application No. 29289/95. Judgment of 25 September 1997.

18 Egyptian Initiative for Personal Rights and INTERIGHTS v Egypt Communication 323/06 decided during the 10th Extraordinary session of the African Commission on Human and Peoples' Right held between 12 and 16 December 2011.
} 
The first victim, a female journalist previously employed at Al Gil Newspaper, in Cairo, claimed that she was pushed to the ground, her clothes torn, her private parts fondled, and her bag and documents seized from her. She further claimed that she lost vital documents during her ordeal with the police.

The second victim, a female journalist at Al Doustour Newspaper, in Cairo, claimed that she was subjected to different forms of physical and emotional abuse, including being thrown to the ground, beaten, her clothes torn, dragged on the ground, sexually abused, hit in the face and called names such as 'whore' and 'slut'. The third victim, who is also a journalist with Al Doustour Newspaper, in Cairo, claimed that she was physically assaulted. She further claimed that when she tried to escape the scene of violent protests, she was accosted by policemen and then was severely beaten, bitten, her hair pulled and ordered to strip naked by some female supporters of NDP.

The fourth victim, a journalist with Nahdat Misr Newspaper, in Cairo, and a member of the Kefaya movement, was equally subjected to various forms of violence and abuse. It is alleged that she was attacked by a group of unidentified men who pushed her against the wall and hit her in her lower abdomen several times until she collapsed on the ground. The complaints alleged a violation of articles 1, 2, 3, 5, 7(1)(a), 9(2), 16, 18(3) and 26 of the African Charter by the respondent State. It was further alleged that the respondent state failed in its obligations to protect the complainants from sexual violence. In its landmark decision, the African Commission denounced acts of violence against African women in all its ramifications. According to the Commission, gender-based violence, including sexual violence is a gross violation of women's rights for which states must be held accountable. Taking into account the lived experiences of African women, the Commission observes that failure of a state to protect women from acts of violence perpetrated by a third party-in public or private-will render the state vicariously responsible for such violation of rights. This is often known as the doctrine of due diligence which was affirmed by the UN General Assembly in its Declaration on Violence against Women. This has been subsequently adopted by the CEDAW Committee in its General Recommendation 19 on violence against women. By the adoption of the due diligence doctrine, the African Commission would seem to be asking the African woman question. For many years, African women have been cowed and silenced by a culture of violence often perpetrated by people close to them. In most cases, gender-based violence, particularly domestic violence and sexual violence by intimate partners, has often been shielded from public scrutiny all in the name of 'private affairs' (Olsen 1983, p. 1497; Naylor 2005, p. 57). Thus, such acts of violence have gone unnoticed or without redressed, forcing African women to endure in silence this grave injustice and threats to their health and well-being. It was not until the Vienna Programme of Action (1993) that the international community declared that violence against women is a violation of women's rights as it impairs them from enjoying their fundamental rights and freedoms.

This progressive approach of the African Commission would seem to coincide with that of other human rights body such as the European Court on Human Rights. For instance, in Aydin v. Turkey, the European Court on Human Rights, while condemning the rape of a Turkish woman in detention, further noted that rape of a detainee under a state 
custody is an abhorrent form of ill-treatment which is unacceptable. In what may be described as responding to the woman question, the Court noted that "rape leaves deep psychological scars on the victim which do not respond to the passage of time as quickly as other forms of physical and mental violence ${ }^{19}$ Consequently, the Court declared that there had been a violation of article 3 of the European Convention relating to the prohibition of torture, inhuman and degrading treatment.

Taking a cue from the CEDAW Committee, the African Commission in the Egyptian Initiative for Personal Rights case reasons that acts of violence against women amount to discrimination in violation of the African Charter and the African Women's Protocol. In particular, the Commission relies on article 1 of the African Women's Protocol and notes that violence is a violation of the provision on equality enshrined in the African Charter and the African Women's Protocol. In arriving at this conclusion, the Commission took into cognisance the particular individual experiences of the complainants, including the molestation and abuse they suffered from their assailants. The Commission reasons that it is obvious that the complainants went through these ordeals because of their gender and that the Egyptian government failed to protect them from the hands of their assailants. To this extent, the Commission concluded that there had been a violation of the right to non-discrimination and equality guaranteed by the African Charter.

By showing sensitivity to the plight of the complainants and acknowledging their lived experiences, the Commission is asking the woman question. The Commission seems to recognise the fact that while men and women are both exposed to violence and human rights abuses during riot or insurrection, the position of women is graver than men because of their susceptibility to sexual harassment and intimidation. Such an approach is faithful to the substantive notion of equality recognised by the African Women's Protocol and CEDAW, which is often aimed at "equalising the starting point" (Fredman 1996, p. 202). Substantive equality also aims at addressing structural differences that perpetuate inequality or discrimination in society. Unlike a formal approach to equality, substantive equality does not only take into consideration an individual's peculiar circumstances, it also strives at achieving equality of opportunity. Moreover, it provides an avenue for remedial measures to be taken to address socio-cultural inequality African women often encounter in society. As noted earlier, the provisions of CEDAW and the African Women's Protocol are couched in a substantive equality language. They seek to not only eliminate de facto but also de jure discrimination. Such an approach coincides with asking the woman question. Furthermore, this approach coincides with the reasoning of feminist scholars. For instance, Fineman (1995, p. 355) has argued that the concept of 'gendered life' is necessary to generate arguments admitting that recognition of difference is crucial to remedying socio-cultural disadvantages often imposed on women. Also, Banda (2005) has noted that African women continue to suffer from suffocating cultural practices, which easily erode their fundamental rights and freedoms. This approach is faithful to eliminating social injustice and upholding the tenet of egalitarianism. In essence, a court or quasi-

\footnotetext{
${ }^{19}$ Aydin v. Turkey (European Court of Human Rights) Application No. 29289/95. Judgment of 25 September 1997.
} 
judicial body cannot afford to turn a blind eye to the disadvantaged position of women in African societies.

More importantly, the Commission considered all the circumstances of the case, including the nature of the violence perpetrated and the derogatory language used against the victims and concluded that there has been a violation of article 18(3) of the African Charter. In addition, the Commission explains that the nature of physical assaults experienced by the complainants, including attempts to touch their 'private and sensitive parts', are peculiar to women. In essence, the complainants were targeted for the acts of violence they suffered simply because they are women. This, according to the Commission, is a clear act of discrimination and cannot be justified under the law. While the Commission recognises that not all discrimination is unlawful, it reasons that the physical and sexual assault targeted at the complainants based on their gender cannot be excused. In buttressing its point, the Commission draws inspiration from the decision of the Inter-American Court on Human Rights' in the Advisory Opinion on the proposed Amendments to the Naturalization Provisions of the Constitution of Costa Rica, where it was noted that ${ }^{20}$ "...no discrimination exists if the difference in treatment has a legitimate purpose and if it does not lead to situations which are contrary to justice, to reason or to the nature of things...”. In the Commission's view, the various acts of violence and molestation of the complainants are not only discriminatory but also amount to serious human rights violations that should not be condoned.

Furthermore, the Commission notes that failure on the part of the Egyptian government to protect the complainants from violence by setting up a judicial structure to punish perpetrators of violence against the complainants is a breach of obligation under international law. In arriving at this conclusion, the Commission relied on the Inter-American Commission's decision in Maria da Penha and Maia Fernandes v. Brazil, ${ }^{21}$ where it was noted that:

Ineffective judicial action, impunity, and the inability of victims to obtain compensation provide an example of the lack of commitment to take appropriate action...This is more or less a reinstatement of the due diligence principle widely recognized in international human rights law. ${ }^{22}$

Indeed, due diligence implies that any violations of human rights occasion by the action of a third party can be imputed to the State if there is evidence of failure on the part of the State to take adequate measures to prevent such violation.

With regard to whether the acts of violence against the complainants amount to a violation of article 3 of the African Charter on equality, the Commission referred to its earlier decision in Zimbabwe Lawyers for Human Rights and the Institute for Human

\footnotetext{
${ }^{20}$ Proposed Amendments to the Naturalization Provisions of the Constitution of Costa Rica, Advisory Opinion OC4/84, January 19, 1984, Inter-Am. Ct. H.R. (Ser. A) No. 4 (1984) para 57.

${ }^{21}$ Maria da Penha v. Brazil (2001) IACHR para.56.

${ }^{22}$ See the Inter-American Court decision in Velasquez Rodriguez v. Honduras (1988) IACtHR, para. 173; see also, Declaration on Violence against Women and General Recommendation 19 of CEDAW
} 
Rights and Development (on behalf of Andrew Barclay Meldrum) v. Republic of Zimbabwe and notes as follows 23 :

The most fundamental meaning of equality before the law under Article 3(1) of the Charter is the right by all to equal treatment under similar conditions. The right to equality before the law means that individuals legally within the jurisdiction of a State should expect to be treated fairly and justly within the legal system and be assured of equal treatment before the law and equal enjoyment of the rights available to all other citizens... The principle that all persons are equal before the law means that existing laws must be applied in the same manner to those subject to them.

One of the criticisms of this case is that the Commission missed the opportunity to diligently apply the provisions of the African Women's Protocol relating to violence against women. While Egypt has not yet signed, or ratified the Protocol, there is nothing preventing the Commission from elucidating its judgment with reference to the Protocol given that it is an instrument of the African Union of which Egypt is a member State. This would have provided the Commission an opportunity to emphasize the importance of the Protocol and the need for all African governments to uphold the spirit and intents of its provisions. Article 4 of the Protocol is one of the strongest provisions protecting women from all forms of violence and detailing steps States must take to ensure that women are fully protected from violence, whether during peace or conflict. The provision was drafted to deal with the spate of gender-based violence, which is almost becoming an epidemic in many parts of Africa. It recognizes the lived experiences of African women and urges African governments to adopt a holistic approach to addressing violence against women. Although the Commission cited article 1 of the African Women's Protocol to highlight the discriminatory aspect of gender-based violence, it ought to have made the link between this provision and provision of article 4. Indeed, linking the violation of article 1 with article 4 of the Women's Protocol would have sent a stronger message to States regarding their obligations to protect women from gender-based violence.

In addition, the Commission fails to fully engage with existing norms and standards that protect women from inequality and abuses in the region. One such important standard is the 2004 Solemn Declaration on Gender Equality adopted by the African Union. During this Declaration, African leaders agreed to take all necessary steps and measures to create an enabling environment that will respect and protect women's rights and ensure gender equality in all human endeavours. Moreover, the remedy provided by the Commission for the violations of the rights alleged falls short of asking the woman question. Rather than ordering reparation and rehabilitation of the victims of sexual abuse, the Commission merely awards damages for violation of the rights of the victims. While award of damages or compensation are necessary, the Commission should have used the opportunity to highlight the need for victims of gender-based

\footnotetext{
${ }^{23}$ Communication 294/2004-Zimbabwe Lawyers for Human Rights and the Institute for Human Rights and Development (on behalf of Andrew Barclay Meldrum) v. Republic of Zimbabwe (ACHPR).
} 
violence to be provided with some form of psychological and medical care for the trauma they experienced. This will be consistent with asking the woman question.

In contrast to the gender-neutral approach of the Commission to some cases before it, lessons can be drawn from gender-sensitive approach of some national courts in the region. For instance, in the case of Ugandan Association of Women Lawyers and 5 others v. The Attorney General, 24 the petitioners filed a case in court to challenge the constitutionality of certain provisions of the Divorce Act, chap 249 of Laws of Uganda, specifically, sections 4(1) and (2), 5, 21-24 and 26, which provide for disparate treatment for men and women. A provision of the Divorce Act requires that a man need only prove adultery to obtain a divorce while a woman must prove aggravated adultery. The Ugandan Constitutional Court reasoned that the contested provisions of the Divorce Act are inconsistent with the Ugandan Constitution since they discriminate on the basis of gender. Article 21 of Ugandan Constitution of 1995 prohibits discrimination on the basis of sex, race, colour, ethnic origin, tribe, birth, creed or religion, social or economic standing, political opinion or disability. More importantly, the Court noted that these provisions of the Divorce Act violate women's constitutional right to equality and are inconsistent with the principle of equality, which is a core value of the Ugandan Constitution. No doubt, this decision of the Ugandan Court is more consistent with asking the woman question, in that the Court questioned the rationale for differential treatment of men and women in divorce matters. Moreover, the Court traced the origin of the Divorce Act to the colonial period and concluded that it represents a patriarchal tradition that has outlived its usefulness, thus, the Court declared the contested provisions as a nullity. This decision serves as a good model of how the court can ask the African woman question in cases relating to gender inequality in general and women's sexual health needs in particular.

\section{Conclusion}

From the discussions in this paper, it is clear that African women have remained subject to cultural practices that are discriminatory against them. Despite the progress and efforts at international and regional levels to address discriminatory practices against women, negative cultural practices have continued to impair African women from enjoying their fundamental rights and freedoms. National courts and regional human rights bodies or tribunals can play an important role by asking the African woman question with regard to cases brought before them. Asking the African woman question will ensure that cases that border on the violation of women's rights are not just treated as one of those cases, but are decided in such a way that they accommodate and contextualize the suffering of women in the region.

Unfortunately, very few decisions of the African Commission have addressed gender based discrimination and the low status of women in African societies. The reason for the dearth of cases before the Commission on this issue is unclear, especially when one considers the great number of organizations working on women's rights in the region. Judging by the decisions of the Commission so far, it does appear that the

\footnotetext{
${ }^{24}$ Constonst. Petitetit. Noo. 2 of 200B)03 [20042004] UGCGCC $\mathbb{1}(3 / 10 / 2004 / 3 / 10 / 2004)$.
} 
Commission is yet to develop a systemic and pragmatic approach to asking the African woman question regarding cases before it. Therefore, it is imperative that the African Commission adopt a consistent and systemic approach to addressing issues bordering on the violation of women's rights in the region. The Commission should always reflect on the gender implications of the outcome of cases brought before it. To do otherwise is to pretend that the suffering and subordination of women in Africa are a farce. It must be borne in mind that one of the purposes of the Sustainable Development Goals (SDGs) is to realize gender equality in every aspect of human endeavour. Therefore, courts and regional human rights bodies must continue to hold African governments accountable to their obligations under international, regional and national documents to eliminate all forms of practices that may prevent women from enjoying their fundamental rights and freedoms. 


\section{References}

Amnesty International. 2010. Sudan: Abolish the flogging of women. London: Amnesty International. Banda, Farina. 2005. Women, law and human rights: An African perspective. Oxford: Hart Publishing. Ba, Maria. 1981. So long a letter. Dakar: Heinemann.

Baderin, Mashood. 2005. Recent developments in the African regional human rights system. Human Rights Law Review 5(1): 117-149.

Bartlett, Katherine. 1990. Feminist legal methods. Harvard Law Review 103(4): 829888.

Bunch, Charlotte. 1995. Transforming human rights from a feminist perspective. In Women's rights, human rights: International feminist perspectives, ed. Peters Julie, and Wolper Andrea, 11-17. London: Routledge.

Cook, Rebecca. 1995a. Human rights and reproductive self-determination. The American University Law Review 44(4): 975-1016.

Cook, Rebecca. 1995b. Women's international human rights law: The way forward. In Human rights of women: National and international perspectives, ed. Cook Rebecca, 3-36. Philadelphia: University of Pennsylvania Press.

Douglas, Heather, Francesca Bartlett, Trish Luker, and Rosemary Hunter (eds.). 2015. Australian feminist judgments: Righting and rewriting law. Oxford: Hart Publishing.

Durojaye, Ebenezer. 2013. 'Woman but not human': Widowhood practices and human rights violations in Nigeria. International Journal of Law, Policy and the Family 27(2): 176-196.

Eboh, Marie. 1997. The woman question: African and Western perspectives. In African philosophy: An: An anthology, ed. Eze Emmanuel, 333-337. Cambridge, MA: Blackwell.

Enright, Máiréad, McCandless, Julie and Aoife O’Donoghue, eds. Forthcoming 2017. Northern/Irish feminist judgments: Judges' troubles and the gendered politics of identity. Oxford: Hart Publishing.

Eisenstein, Hester. 1984. Contemporary feminist thoughts. London: Allen \& Unwin.

Evans, Malcolm, and Rachael Murray (eds.). 2008. The African charter on human and peoples' rights: The system at work. Cambridge: Cambridge University Press.

Fineman, Martha. 1995. Feminist theory and law. Harvard Journal of Law and Public Policy 18(2): 349-369.

Fredman, Sarah. 1996. Less equal than others-Equality and women's rights. In Understanding human rights, ed. Gearty Conor, and Tomkins Adams. London: Mansell.

Forum for African Women Educationists (FAWE). 1995. Education of girls and women in Africa. Lusaka: Forum for African Women Educationists.

Gilligan, Carol. 1982. In a different voice: Psychological theory and women development. Cambridge, Mass: Harvard University Press.

Hunter, Rosemary, Clare McGlynn, and Erika Rackley (eds.). 2010. Feminist judgments: From theory to practice. Oxford: Hart Publishing.

Imam, Aisha. 2000. Of laws, religion and women's rights: Women's rights in Muslim law. In The place of women under Sharia, ed. Constitutional Rights Project. Lagos: Constitutional Rights Project. 
Joyner, Christopher. 1997. United Nations and International Law. Cambridge: Cambridge University Press.

Lees, Sue, and Jenny Mellor. 1986. Girls' rights. In The rights of children, ed. Franklin Bob. Oxford: Basil Blackwell.

Mackinnon, Catherine. 1982. Feminism, Marxism, method and the state: An agenda for theory. In Feminist theory: A critique of ideology, ed. Keohane Nannerl, Rosaldo Michelle, and Barbara Gelpi. Brighton: Harvester Press.

Margalit, Avishai. 2003. The ethics of memory. Cambridge: Harvard University Press.

Naylor, Nikki. 2005. Cry the beloved continent. Exploring the impact of HIV/AIDS and violence on women's reproductive and sexual rights in Southern Africa. Journal of Juridical Science 30(2): 52-79.

Nzegwu, Nkiru. 2006. Family matters: Feminist concepts in African philosophy of culture. Albany, NY: Suny Press.

Odejide, Abiola. 2007. "What can a woman do?" Being women in a Nigerian University. Feminist Africa 8: 42-59.

Olsen, Frances. 1983. The family and the market: A study of ideology and legal reform. Harvard Law Review 96(7): 1497-1578.

Oyewumi, Oyeronke. 1997. The invention of women: Making an African sense of Western gender discourse. Minneapolis: University of Minnesota Press.

St. John-Stevas, Norman. 1956. Obscenity and the law, 70-74. London: Secker and Warburg.

Stanchi, Kathryn, Berger Linda, and Bridget Crawford (eds.). 2016. U.S. feminist judgments: Rewritten opinions of the United States Supreme Court. Cambridge: Cambridge University Press.

Tamale, Sylvia. 2004. Gender trauma in Africa: Enhancing women's link to resources. Journal of African Law 48(1): 50-62.

Tamale, Sylvia. 2008. The right to culture and the culture of rights: A critical perspective of women's sexual rights in Africa. Feminist Legal Studies 16(1): 4769.

UNICEF. 2013. Female genital mutilation/cutting: A statistical overview and exploration of the dynamics change. New York: UNICEF.

UNICEF. 2015. A profile on child marriage in Africa. New York: UNICEF.

UNFPA. 2012. Giving birth should not be matter of life and death. New York: UNFPA.

United Nations. 1993. Vienna declaration and programme of action UN Doc A/CONF 157/24 Part 1 ch 1 ch III.

United Nations. 1994. Report of the international conference on population and development (ICPD) 7, UN Doc A/CONF.171/13 (1994).

United Nations. 1995. Fourth world conference on women (FWCW) Beijing held on 15 September 1995 A/CONF.177/20.

Viljoen, Frans. 2012. International human rights law in Africa. Cambridge: Cambridge University Press. WHO, UNICEF, UNFPA and WORLD BANK. 2014. Trends in maternal mortality: 1990-2013. Geneva: WHO.

WHO. 2016 'FGM Fact sheet.' http://www.who.int/mediacentre/factsheets/fs241/en/. Accessed 25 Feb 2016.

Wishik, Heather Ruth. 1985. To question everything: The inquiries of feminist jurisprudence. Berkeley Women's Law Journal 64(1): 64-77. 